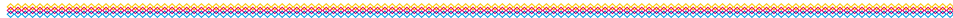

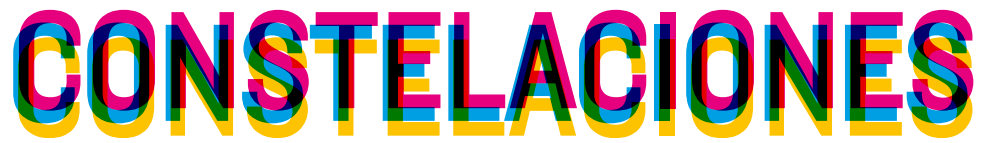

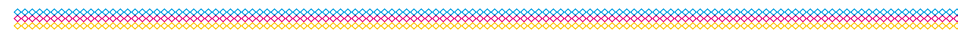




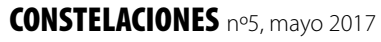

Revista de Arquitectura de la Universidad CEU San Pablo

Architecture Magazine of CEU San Pablo University

Periodicidad anual

Annual periodicity

COMITÉ DE REDACCIÓN EDITORIAL COMMITTEE

\section{Dirección Directors}

Juan García Millán

Santiago de Molina

Jefa de Redacción Editor in Chief

Covadonga Lorenzo Cueva

Secretario de Redacción Editorial Clerk

Rodrigo Núñez Carrasco

Maquetación y producción Design and production

María Fernández Hernández

Clara Martínez-Conde Rubio

Revisión de textos en inglés English Editing

Carlota Sáenz de Tejada Granados

Responsable Web Web Page Manager

María Isabel Castilla Heredia

Diseño Original Original Design

Juan Roldán Martín

\section{Vocales Board Members}

María Dolores Gómez Pulido. Escuela Politécnica Superior, Universidad CEU San Pablo, Madrid

Rocío Carvajal Alcaide. Escuela Politécnica Superior, Universidad CEU San Pablo, Madrid

Clara Eugenia Maestre Galindo. Escuela Politécnica Superior, Universidad CEU San Pablo, Madrid

\section{CONSEJO EDITORIAL EDITORIAL BOARD}

Beatriz Colomina. School of Architecture, Princeton University, New Jersey

Carmen Díez Medina. Escuela de Ingeniería y Arquitectura, Universidad de Zaragoza

María Antonia Frías Sargadoy. Escuela Técnica Superior de Arquitectura, Universidad de Navarra

Juan Miguel Hernández Léon. Escuela Técnica Superior de Arquitectura, Universidad Politécnica de Madrid

Juan José Lahuerta Alsina. Escuela Técnica Superior de Arquitectura, Universidad Politécnica de Cataluña, Barcelona

Eduardo Leira Sánchez. Ex director del Plan General de Ordenación Urbana, Madrid

Joaquín Medina Wamburg. Facultad de Aquitectura Diseño y Urbanismo, Universidad de Buenos Aires

Zaida Muxí Martínez. Escuela Técnica Superior de Arquitectura, Universidad Politécnica de Cataluña, Barcelona José Joaquín Parra Bañón. Escuela Técnica Superior de Arquitectura, Universidad de Sevilla

Víctor Pérez Escolano. Escuela Técnica Superior de Arquitectura, Universidad de Sevilla

Fernando Pérez Oyarzún. Escuela de Arquitectura y Diseño, Pontificia Universidad Católica, Santiago de Chile Judith Sheine. School of Architecture and Allied Arts, University of Oregon, Portland

Andrés Walliser Martínez. Global Design, New York University, Nueva York

\section{ISSN 2340-177X}

Depósito legal M-13872-2013

(c) de los textos, sus autores

(c) de las imágenes autorizadas

(C) Revista Constelaciones

๑) Escuela Politécnica Superior, Universidad CEU San Pablo

Universidad CEU San Pablo

Escuela Politécnica Superior

Urbanización Montepríncipe, s/n

Alcorcón, 28925. Madrid (España)

constelaciones@eps.ceu.es

www.uspceu.es

www.revistaconstelaciones.wordpress.com

Edición Edition

Fundación Universitaria San Pablo CEU

Madrid, España

Impresión Printing

VA Impresores

Impreso en España Printed in Spain

Distribución Distribution

CEU Ediciones

\author{
INDEXACIÓN INDEXING \\ Índices Index \\ Latindex \\ Avery Index \\ ErihPlus \\ MIAR
}

Bases de datos Data bases

Dialnet

Índices en evaluación Evaluation Index

Web of Science

Scopus

Dulcinea

EBSCO

Sherpa Romeo
Los textos que componen Constelaciones se obtienen mediante convocatoria pública. Para que los trabajos recibidos entren en el proceso de selección de los artículos a publicar deben ser trabajos originales no publicados anteriormene, con una extensión recomendada de 3.000 palabras, título, resumen (un máximo de 150 palabras) y palabras clave (un mínimo de cuatro palabras), en español y en inglés. Tras haber cumplido estos requisitos (y los correspondientes incluidos en las normas editoriales de la revista, disponibles para consulta en formato digital desde el comienzo de la convocatoria), tiene lugar un proceso de revisión y evaluación de los artículos previa aceptación de los mismos para su publicación. Para acometer dicho proceso, y con el fin de asegurar la calidad de los contenidos, la revista Constelaciones recurre a evaluadores externos a la institución editora y anónimos (cada artículo es evaluado por dos de ellos) encargados de someter a crítica los mismos. Todos los artículos de investigación publicados en esta revista han pasado por dicho proceso. La recepción de artículos se extendió hasta el 30 de septiembre de 2016. Texts included in Constelaciones are obtained by public announcement. Only original papers that have not been previously published will be included in the process of selection of articles. They should not exceed 3.000 words and should include a title, an abstract (no more than 150 words) and keywords (a minimum of four words), in Spanish and English. After having fulfilled these requirements (and those included in magazine editorial standards, available for consultation from the beginning of the Call for Papers), occurs a process of review and evaluation of articles upon acceptance of them for publication. To undertake this process, and in order to ensure the quality of the contents, Constelaciones turns to external and anonymous evaluators to the institution (each article is evaluated by two of them) responsible for the critic. All the articles published in this journal have undergone this process. The deadline for reception was extended until September 30, 2015.

Todos los derechos reservados. Esta publicación no puede ser reproducida, ni en todo ni en parte, ni registrada, ni transmitida, ni almacenada en ninguna forma ni por ningún medio, sin la autorización previa y por escrito del equipo editorial. En este número se han utilizado algunas imágenes de las que no se ha podido identificar al propietario de los derechos. En estos casos hemos entendido que las imágenes son de libre uso. En caso de identificar alguna de estas imágenes como propia, por favor, póngase en contacto con la redacción de Constelaciones. Los criterios expuestos en los diversos artículos de la revista son responsabilidad exclusiva de sus autores y no reflejan necesariamente los que pueda tener el equipo editoral. El equipo editorial de la revista no se responsabiliza de devolver la información enviada a la redacción a no ser que se le solicite expresamente. All rights reserved. This publication cannot be reproduced, in whole or in part, nor registered, transmitted or stored in any form or by any means, without the written permission of the Editorial team. In this issue some images were used without knowing the owner of the rights. In these cases, we have understood that the images are free of use. In case you identify written permission of the Editorial team. In this issue some images were used without knowing the owner of the rights. In these cases, we have understood that the images are free of use. In case you identify
any of these images as your own, please, contact with the Editorial staff of Constelaciones. The opinions expressed in this issues's articles are entirely the responsibility of their authors and are not necessarily shared by the editors of this journal. The publisher don't take responsibility for returning submitted material which is not expressly requested. 

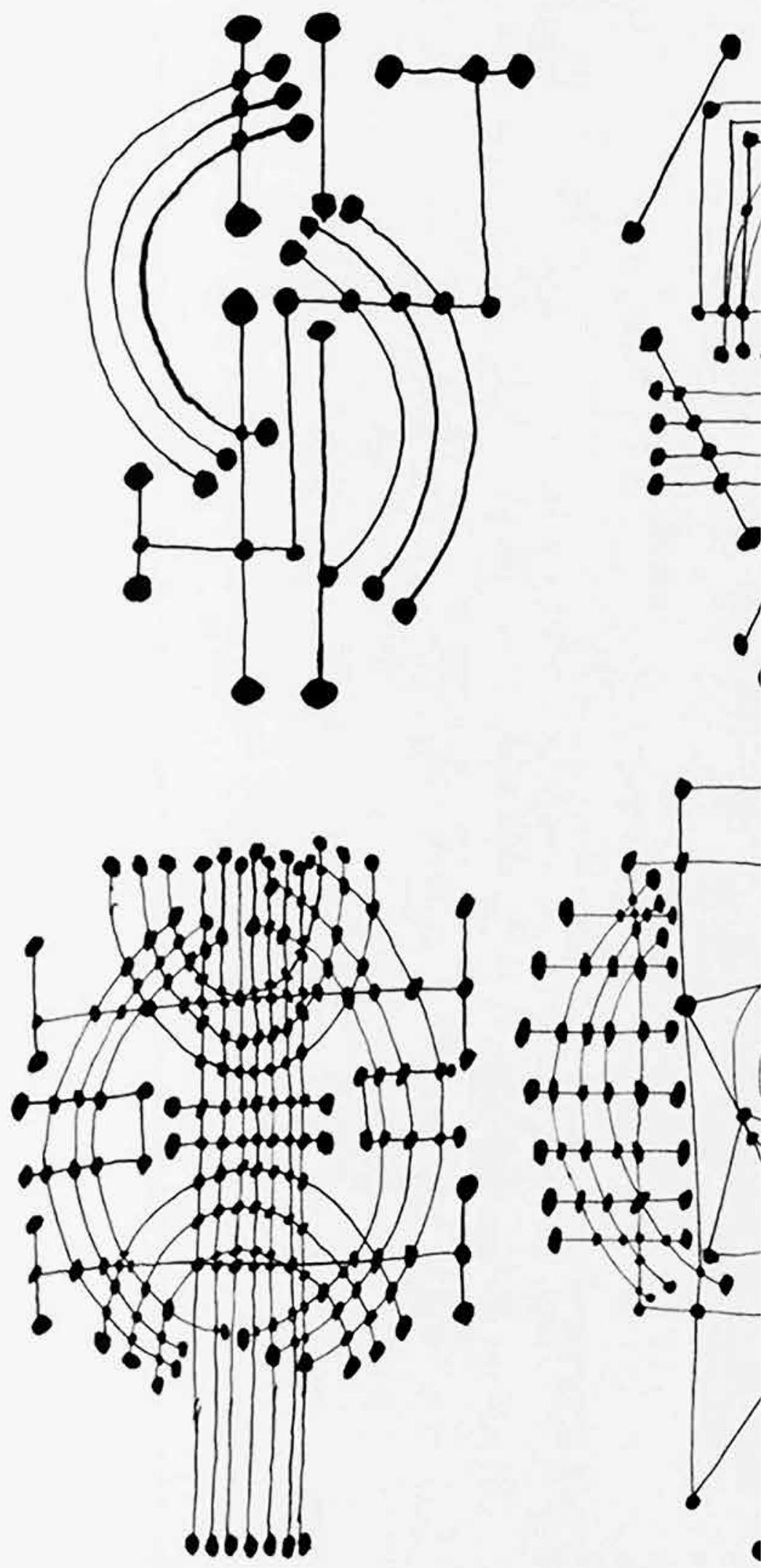


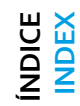

จ

ก)

品

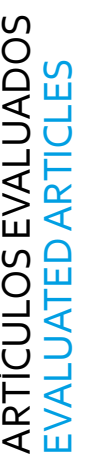

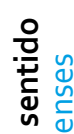

बํำ

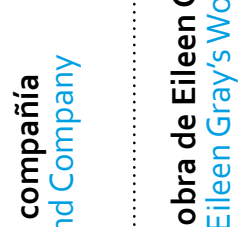

드.

ฮั

茄

:

ที่ ปั อ

苦云

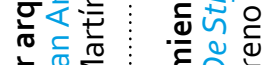

过

ह $\frac{2}{3}$

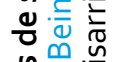

눈

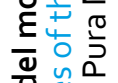

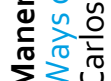

นับ

음

๗ั

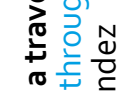

号

궁워

뜬

원

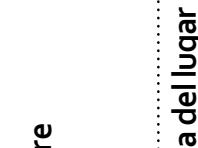

임

ส

응

离

$: \frac{\mathscr{2}}{ \pm}$

을

tั

ग

ํํำ

ํㅡㄹ

:

응 $\frac{\cup}{0}$

บับ

인

든

冚

号京

ब

ฮั

을

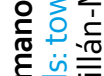

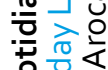

언

으 $\frac{\pi}{\pi}$

产

등 똥

告崖

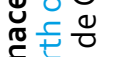

ํํㄴ

일

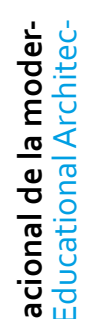

高
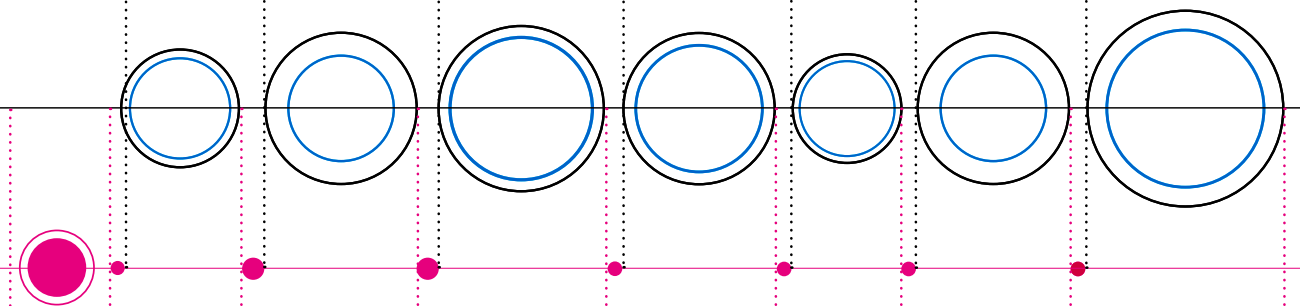

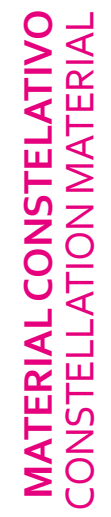

岂㟧

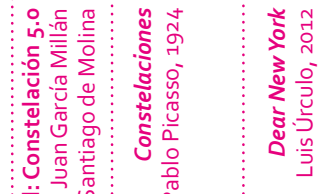

$=\quad \stackrel{m}{\sim}$

$\stackrel{\bullet}{v}$
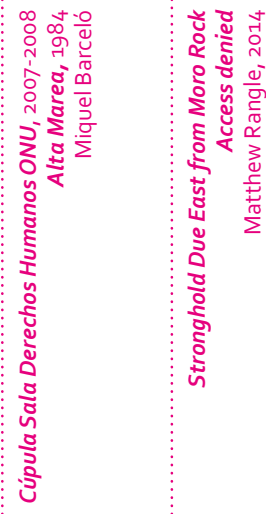

$\overline{6}: \AA$

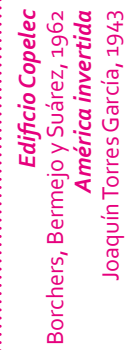

$\infty$

응 


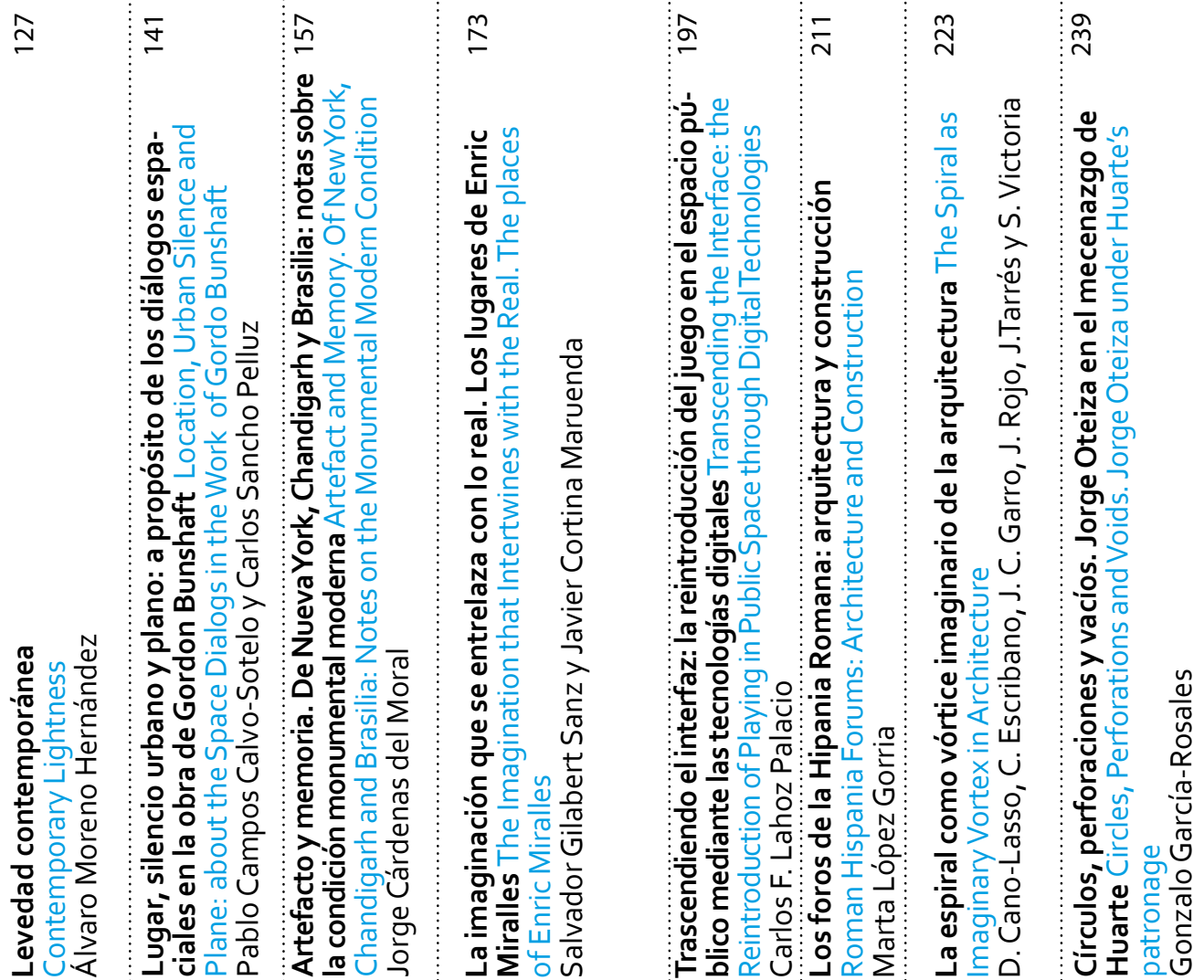
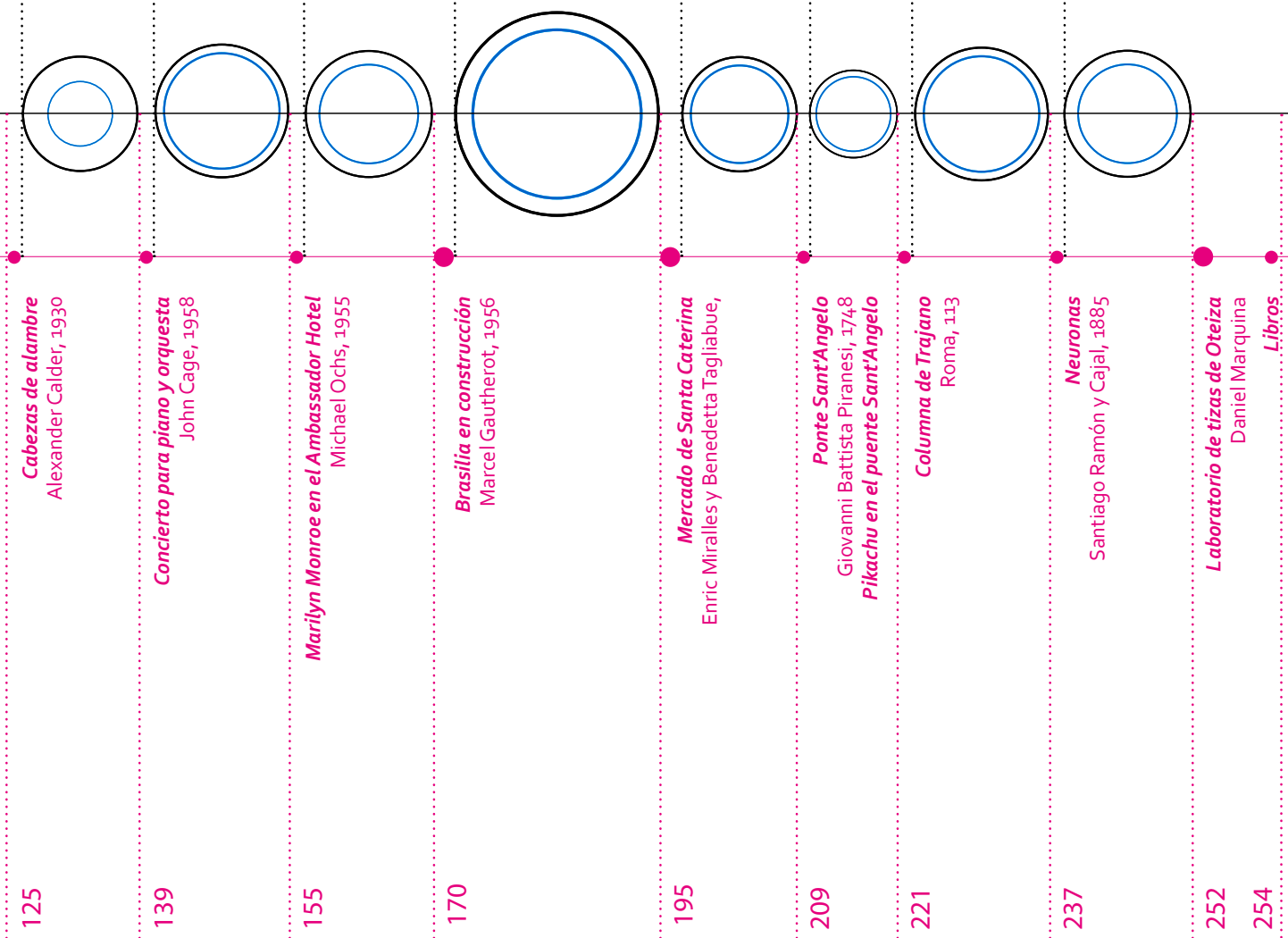


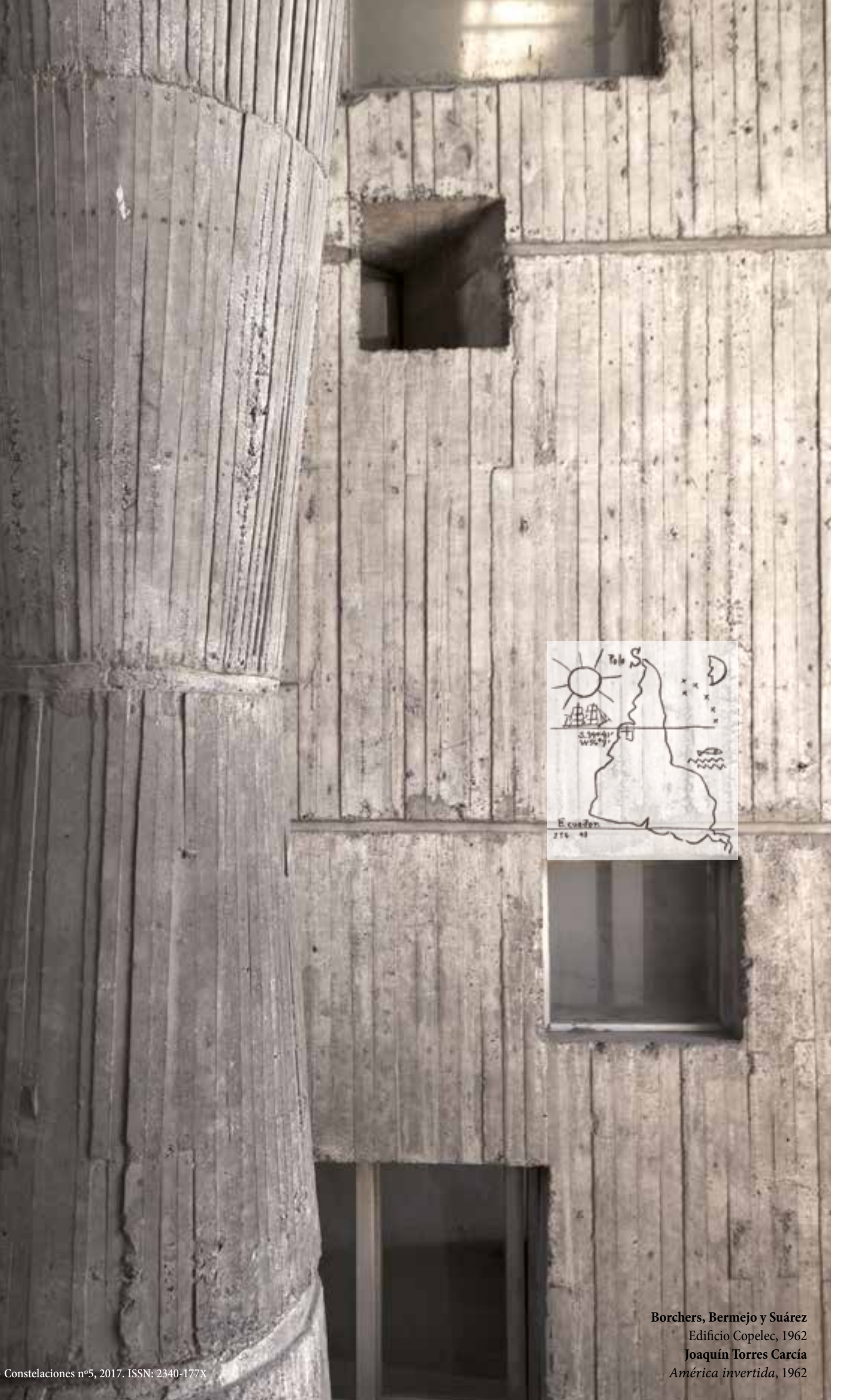




\title{
Tradición y ruptura en la arquitectura educacional de la modernidad en Chile
}

\section{Tradition and Rupture in the Educational Architecture of Modernity in Chile}

\author{
Cristóbal Molina Baeza \\ Consejo Nacional de la Cultura y las Artes, Gobierno de Chile \\ Traducción Translation Daniela Sanhueza
}

\section{Palabras clave Keywords}

Arquitectura educacional, colegios, modernidad, pedagogía, control medioambiental, abstracción, Chile

Educational architecture, schools, modernity, pedagogy, environmental control, abstraction, Chile

\section{Resumen}

A mediados del siglo XX se forjó en Chile una suerte de tradición en torno a la arquitectura escolar, que fue plasmada en una serie de obras y proyectos notables. Algunas de ellas fueron obra de figuras locales como Sergio Larrain Garćáa-Moreno, Emilio Duhart, Mario Pérez de Arce, Alberto Piwonka. Todos ellos tuvieron un protagonismo principal en la materialización de las ideas de la modernidad en este país. En esos edificios escolares parecen coincidir dimensiones técnicaconstructivas, de control ambiental, de diseño paisajístico y de aplicación de criterios de abstracción formal, que dieron respuestas al problema educativo con un novedoso abanico de posibilidades.

El inicio de esa tradición local en Chile puede ser situada a partir del colegio del Verbo Divino, adjudicado en un concurso por Larrain, Duhart, Pérez de Arce y Piwonka en 1948, que fue un proyecto ejemplar de la arquitectura escolar más radical y en sintonía con la modernidad arquitectónica en Chile por esos años.

En esas obras escolares es posible establecer además lecturas en torno a temáticas más generales, como la técnica constructiva en un país sísmico y su expresión plástica, y en algunos casos, en la integración de las artes 0 el paisajismo al proyecto arquitectónico, para dar respuesta desde la arquitectura a las necesidades pedagógicas de la enseñanza.

\begin{abstract}
A sort of tradition around educational architecture was forged in Chile in the mid-twentieth century, embodied by a series of remarkable works and projects. Some of these were the work of local figures such as Sergio Larrain García-Moreno, Emilio Duhart, Mario Pérez de Arce or Alberto Piwonka. All of them had a leading role in the materialization of the ideas of modernity in this country.

Technical-constructive dimensions, environmental control, landscape design and implementation of formal abstraction criteria, all seem to meet in these scholastic buildings, providing answers to the educational problem with a novel range of possibilities.

The onset of this local tradition in Chile can be placed in the Verbo Divino School, awarded by/to Larrain, Duhart, Pérez de Arce and Piwonka in 1948; an exemplary project of the most radical scholastic architecture, attuned to the architectural modernity of those years in Chile.

In these scholastic works, it is also possible to establish readings around more general topics, such as the constructive technique in a seismic country and its plastic expression, and in some cases, the integration of the arts or landscaping into the architectural project, meeting the pedagogic needs of education by means of architecture.
\end{abstract}


A mediados del siglo xx se forjó en Chile una suerte de tradición en torno a la arquitectura educacional, que fue plasmada en una serie de obras y proyectos notables que han trascendido por su aporte y singularidad como una de las mejores facetas de la producción arquitectónica chilena por esos años. Esa tradición significó además, una ruptura con una usanza de modernización anterior, en especial con aquellos establecimientos de la élite socioeconómica, así como con los ejemplos que dejó la labor social y pedagógica impulsada tanto por el Estado, a través de sociedades anónimas, como por instituciones privadas dedicadas a la enseñanza, que dieron forma a la arquitectura educacional en los años treinta y cuarenta.

Los mejores ejemplos de esa nueva tradición fueron responsabilidad de algunas de las figuras más relevantes a nivel local, en el contexto del ingreso, asimilación y desarrollo de las ideas de la modernidad, como fueron los arquitectos y profesores Sergio Larrain García-Moreno, Emilio Duhart, Mario Pérez de Arce, Alberto Piwonka y los integrantes de la oficina Bresciani, Valdés, Castillo y Huidobro, entre otros. Todos ellos tuvieron un protagonismo principal en la materialización de esos planteamientos en el ejercicio profesional de la arquitectura en ese país, siendo además un grupo cercano de amigos que se relacionaban profesional y académicamente en el cuerpo docente de la Escuela de Arquitectura de la Universidad Católica de Chile. Ellos fueron además quienes lideraron la reforma de esa escuela, en un proceso largo y complejo de cambios que se puede fechar en 1949, (1) aunque algunos de sus alcances se iniciaron antes y su total transformación sucedió en los años inmediatamente posteriores.

El inicio de esa tradición local en Chile puede ser situado a partir de la construcción del Colegio de la Congregación del Verbo Divino, adjudicado a Larrain, Duhart, Pérez de Arce y Piwonka en un concurso de arquitectura en 1948. Ese fue un proyecto innovador en Chile, que simboliza una ruptura con la tradición anterior y fue un ejemplo de la arquitectura educacional más radical y en sintonía con la modernidad por esos años, representando un cambio en la concepción del espacio pedagógico que influenció al conjunto de la obra arquitectónica docente posterior.

In the mid-20th century in Chile, a kind of tradition was forged around educational architecture, materialized in a series of outstanding works and projects that have transcended by their contribution and uniqueness as some of the best expressions of Chilean architectural production during those years. In addition, this tradition represented a break from previous modernization, especially from the establishments of the socioeconomic elite, as well as some examples like state-run social and pedagogical labor left through corporations or private institutions dedicated to education, which shaped educational architecture in the thirties and forties.

The best examples of this new tradition came directly from some of the most relevant local figures in the context of the access, assimilation and development of ideas about modernity, such as the architects and professors Sergio Larrain García-Moreno, Emilio Duhart, Mario Pérez de Arce, Alberto Piwonka and members of the Bresciani, Valdés, Castillo and Huidobro Office, among others. All of them, having a leading role in the materialization of these approaches in the professional practice of architecture in the country, were also a close group of friends, professionally and academically connected as the faculty staff at the School of Architecture of the Universidad Católica de Chile. They also led the reform at that college, in a long and complex process of change that can be dated to 1949, (1) although its expressions began earlier, and its complete consolidation took place during the subsequent years. 
En ese sentido, el Colegio del Verbo Divino fue el primero en el país que se planteará como una sucesión de pabellones lineales organizados en torno a patios y jardines, articulados por una red de corredores cubiertos, cuya estrategia de organización y composición de alzados y detalles contribuirá al control medioambiental necesario para incrementar el desarrollo de la docencia y a acentuar la expresión formal y abstracta de su arquitectura. Esas condiciones serán ensayadas y replicadas, con variantes, en otros proyectos educacionales que realizarán en años posteriores -ya sea en forma individual o colectiva- por esos mismos arquitectos.

Muchas de las ideas y criterios que por primera vez se ensayan en el Colegio del Verbo Divino (1948-1975) pueden ser visibles en otras construcciones educacionales, como en el Seminario Pontificio de Santiago (1949-1958), de Larrain, Duhart, Mönckeberg y Fontecilla; el Liceo de la Alianza Francesa (1954-1962), de Larrain y Duhart; en el Compañía de María de Apoquindo (1955-1958), de Larrain, Duhart y Covarrubias; en la Escuela Naval de Valparaíso (1956-1975), de un numeroso equipo liderado por Pérez de Arce; en la Universidad Técnica del Estado (1957-1967), de Bresciani, Valdés, Castillo, Huidobro y otros asociados y en el Colegio San Ignacio El Bosque (19581972), de Piwonka y Schmidt, entre otras obras memorables que fueron levantadas en esos años en la zona central de la nación sudamericana.

La arquitectura educacional en Chile hacia 1948. Esa aproximación a la arquitectura educacional era diametralmente diferente a la que en ese momento se conocía en ese país. Los mejores ejemplos construidos en los años treinta y cuarenta respondían a una lógica distinta y a un lenguaje arquitectónico que se había caracterizado por propuestas más discretas y conservadoras, testimonios de una etapa de transición hacia las ideas más maduras de la modernidad. En esa línea destacan los ejemplos que impulsó la corporación educacional de derecho privado sin fines de lucro llamada Sociedad de Instrucción Primaria (SIP), cuya notable labor pedagógica y social perdura hasta el día de hoy, y que en su legado ha dejado obras tan relevantes como las escuelas Hermanos Matte (1935) (Fig. 1) o Arriarán (1942), cuyos

innovative project for Chile, symbolizing a break from previous traditions, and an example of the most radical educational architecture, in tune with the modernity of those years, representing a change in the conceptions of pedagogical space which influenced all future production in this field.

In that sense, Verbo Divino School was the first in the country to propose the succession of linear pavilions organized around courtyards and gardens, articulated by a network of covered corridors. Such organizational and compositional strategy of elevations and details contributed to the environmental regulation needed for the proper development of schooling and emphasized the formal and abstract expression of its architecture. These conditions would soon be tested and replicated, with variants, in other educational endeavors carried out in later years -either individually or collectively- by the same architects.

Many of the ideas and criteria, first tested at the Verbo Divino School (1948-1975) can be seen today in other educational constructions including: Seminario Pontificio in Santiago (Larrain, Duhart, Mönckeberg and Fontecilla, 1949-1958); Alianza Francesa School (Larrain and Duhart, 1954-1962); Compañía de María de Apoquindo School (Larrain, Duhart and Covarrubias, 1955-1958); Valparaiso Naval School (led by Pérez de Arce and an extensive team, 1956-1975); Universidad Técnica del Estado (Bresciani, Valdés, Castillo, Huidobro and other associates, 1957-1967) and San Ignacio El Bosque School (Piwonka and Schmidt, 1958-1972), as well as other memorable works that were created in those years in the central region of that South American nation. 


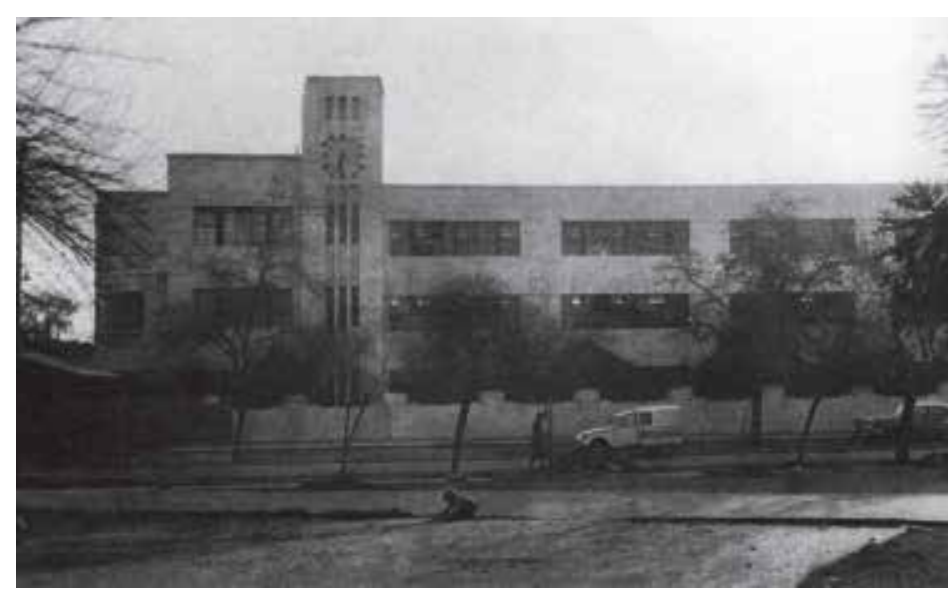

proyectos fueron responsabilidad de la oficina de Gustavo Mönckeberg y José Aracena. Esa arquitectura se transformó además, en un modelo que fue replicado durante muchos años en la labor de la Sociedad Constructora de Establecimientos Educacionales (SCEE), sociedad anónima creada en 1937 que edificó un gran número de escuelas a lo largo de ese territorio nacional y que tuvo como proyectistas a esos mismos arquitectos. (2) La arquitectura impulsada por esas instituciones se caracterizaba por la funcionalidad, luminosidad e higiene del espacio educativo y se resolvía, a través de macizas estructuras en hormigón armado desprovistas de ornamentos. El legado de esa producción arquitectónica aún es visible a lo largo de Chile, en las principales ciudades y en muchas pequeñas localidades.

En general, esas construcciones definían el espacio educacional en torno a edificios de tres o cuatro niveles, que se disponían a lo largo del perímetro del solar, dejando al interior un gran y único patio. En su expresión formal, esos edificios presentan un lenguaje arquitectónico que los hace reconocibles: un elemento vertical y jerárquico que domina el conjunto y que recoge

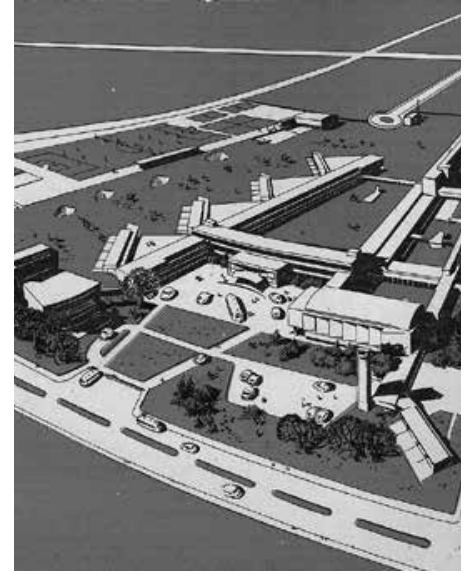

Fig. 1. Escuela Hermanos Matte (1935) Gustavo Mönckeberg y José Aracena. Hevia, P., Fernández, J. y Home, D. Una experiencia educativa: Sociedad de Instrucción Primaria. 150 años. Santiago: Origo, 2010 Fig. 2. Perspectiva del anteproyecto de Costabal y Costabal, primer premio en el concurso para el nuevo Colegio de los Sagrados Corazones de Manquehue en 1948. Revista Arquitectura y Construcción, n. 14 de 1948

Educational Architecture in Chile around 1948. This aforementioned approach to educational architecture was utterly different from the one known in the country at the time. The best examples of constructions from the thirties and forties corresponded to a different logic and to an architectural language characterized by more discreet and conservative proposals, testimonies of a transitional stage towards the more mature ideas of modernity. In this line, some important examples are those proposed by the private non-profit educational corporation called Sociedad de Instrucción Primaria (SIP) - Association for Primary Education- whose remarkable pedagogical and social work continues until today, and that in its legacy has left such works as the Hermanos Matte School (1935) (Fig. 1) or Arriarán School (1942), whose architectural projects were the responsibility of Gustavo Mönckeberg \& José Aracena Office. Furthermore, this architecture was transformed into a model that was replicated for many years in the work of the Sociedad Constructora de Establecimientos Educacionales (SCEE) -Building Society for Educational Establishments- a company created in 1937 that built numerous schools throughout the national territory and whose planners were those same architects.(2) The architectural style promoted by these institutions was characterized by the functionality, luminosity and hygiene of the educational space, and was achieved through massive structures of reinforced concrete devoid of ornament. The legacy of this architectural production is still visible throughout Chile, in its main cities and many small towns.

In general, these constructions developed the educational space with buildings of three or four stories, that were arranged along the perimeter of the lot, leaving a single great courtyard in the interior. In their formal expression, these buildings present an architectural language that makes them recognizable: a vertical and hierarchical element that dominates the 
las circulaciones entre los niveles, que contrasta con la marcada horizontalidad de los volúmenes y los rasgos que se dibujan en vanos y ventanas. Sin embargo, más allá del evidente aporte pedagógico que significaron, esos edificios carecían de condiciones para un mayor contacto con las áreas exteriores y la naturaleza, un mayor asoleamiento. También carecían de una escala que ayudara a diferenciar las diferentes etapas de la enseñanza.

Una experiencia similar y simultánea al Colegio del Verbo Divino y que puede representar también una ruptura con la tradición instaurada en el país por la SIP o la SCEE, fue el anteproyecto no construido por Eduardo Costabal y Jorge Costabal para el nuevo Colegio de los Sagrados Corazones de Manquehue, (Fig. 2) adjudicado también en un concurso de anteproyectos de arquitectura. (3) El anteproyecto de Costabal y Costabal será descartado por esa congregación religiosa, frustrando el aporte que pudo tener esa propuesta en el desarrollo de la arquitectura educacional en ese país.

El origen de esas ideas. A finales de los años cuarenta, Larrain ya tenía un reconocido prestigio como arquitecto y había sido uno de los precursores del ingreso de la arquitectura moderna en ese país al final de la década del
Fig. 3. Acalanes Union High School (1940-1950) Ernest J. Kump Jr. y Charles H. Franklin. Built in USA 1932-1944. The Museum of Modern Art, New York.

Fig. 4. Acalanes Union High School (1940-1950) Ernest J. Kump Jr. y Charles H. Franklin. Roth, Alfred. The New School. Girsberger, 1950
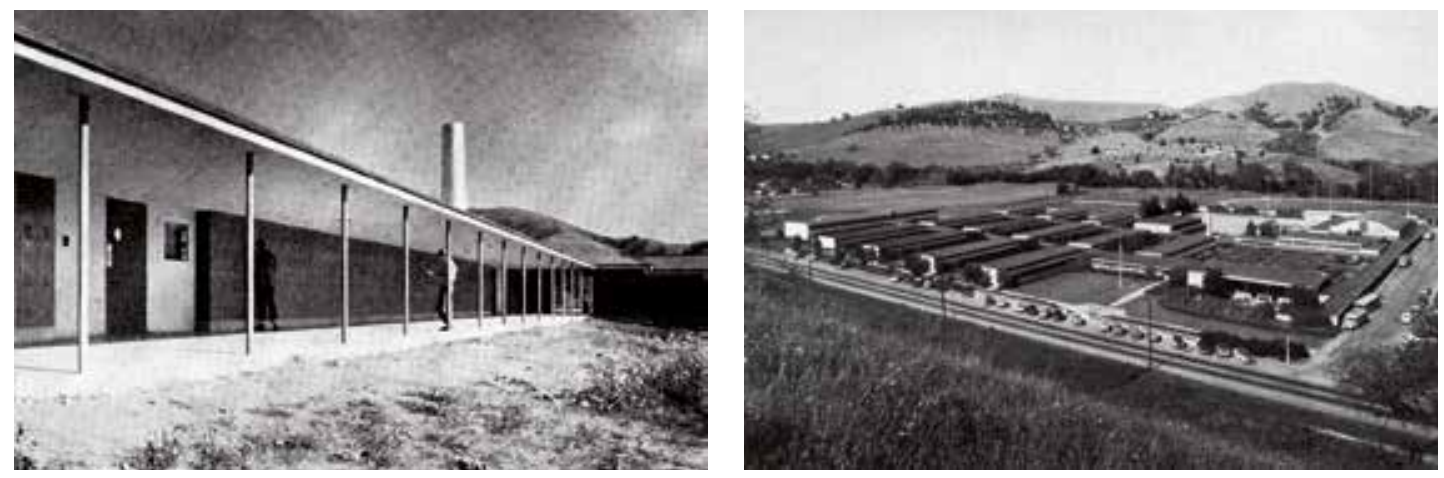

whole structure which gathers the circulations between levels, and that contrasts with the marked horizontality of the volumes and the characteristics that appear in thresholds and windows. However, beyond their obvious pedagogical contribution, these buildings lacked the conditions for better contact with outdoor areas and nature, and for better access to direct sunlight. Additionally, they lacked a scale to help differentiate the different educational levels.

A similar and concomitant experience to Verbo Divino School, which may also represent a break with the tradition established in the country by SIP or SCEE, was the preliminary design project by Eduardo Costabal and Jorge Costabal for the new Sagrados Corazones School in Manquehue, (Fig. 2) also awarded in an architectural competition for preliminary architectural design,(3) which was never built. This project by Costabal \& Costabal was rejected by the religious congregation, thwarting the contribution that this proposal could have had in the development of educational architecture in the country.

The Origin of these Ideas. By the late forties, Larrain already had a recognized standing as an architect and had been one of the precursors of the emergence of modern architecture in that country by the end of the twenties. He had been the professor and supervised Duhart, Perez de Arce and Piwonka's final thesis projects, who began some of the most recognized professional practices in Chile in those years. This group was actively involved in teaching at the School of Architecture of the Universidad Católica de Chile, where Larrain, Duhart and Perez de Arce taught such subjects as architecture studio projects, and Piwonka, along with Alberto Cruz, abstract teachings derived from the Bauhaus pedagogy for students in the initial stages of the architectural degree. 
veinte. Él había sido profesor y había dirigido los proyectos de final de carrera de Duhart, Pérez de Arce y Piwonka, quienes por esos años iniciaban algunas de las prácticas profesionales que serán de las más reconocidas en Chile. Ese grupo estaba estrechamente vinculado con la docencia en la Escuela de Arquitectura de la Universidad Católica de Chile, donde Larrain, Duhart y Pérez de Arce dictaban las asignaturas de proyectos y Piwonka iniciaba, junto a Alberto Cruz, la enseñanza abstracta derivada de la pedagogía de la Bauhaus en la etapa inicial de la carrera de Arquitectura.

Si bien Larrain había visitado la Bauhaus y había conocido las vanguardias parisinas en la década de los años veinte, no será hasta mediados de los años cuarenta cuando este grupo trabará contacto directo con figuras internacionales de la arquitectura moderna. Entre esas experiencias será especialmente relevante la relación de Duhart con Gropius en la GSD de Harvard y con diferentes arquitectos, críticos y artistas que formaban parte de esa comunidad académica. (4) Sin embargo, para efecto de las temáticas de arquitectura educacional, será aún más importante su experiencia posterior como colaborador de Ernest J. Kump Jr. en San Francisco, Estados Unidos. Kump era un reconocido experto en arquitectura educacional. Desde 1937 estaba asociado con Charles H. Franklin en la firma Franklin \& Kump. Dicha oficina había sido responsable de un gran número de edificios educacionales, donde destacaba la afamada Acalanes Union High School (Figs. 3 y 4 ) iniciada en 1940, que será un referente en los Estados Unidos y será incluida en la exposición del MoMA de Nueva York, Built in the USA since $1932 \mathrm{y}$ en el libro de Alfred Roth, The New School, como uno de los ejemplos más destacados de la arquitectura educacional por esos años.

A partir de los contactos de Duhart en Estados Unidos, de su estadía en el atelier de Le Corbusier en 1952 y de otras instancias determinantes, como la estadía docente de Josef Albers en la Universidad Católica de Chile en 1953, (5) a este grupo de arquitectos se les abrirán más referencias formales, pudiendo calibrar la contribución de su trabajo a la cultura arquitectónica.

Although Larrain had visited the Bauhaus and had known of the Parisian avant-gardes in the twenties, it is not until the mid-forties that this group made direct contact with international figures of modern architecture. Among those experiences, Duhart's relationship with Gropius at Harvard's GSD, and with different architects, critics and artists belonging to that academic community, (4) were especially relevant. However, for educational architecture issues, his later experience as a collaborator of Ernest J. Kump Jr. in San Francisco at the United States, would prove to be even more important. Kump was a renowned expert in educational architecture. He was the associate of Charles H. Franklin at Franklin \& Kump since 1937. That firm had been responsible for a large number of educational buildings, including the famous Acalanes Union High School (Figs. 3 \& 4) initiated in 1940, which became a reference in the United States, and their work will be included in the MoMA exhibition in New York, Built in the USA since 1932, as well as in Alfred Roth's book, The New School as one of the most outstanding examples of educational architecture in those years.

Duhart's contacts in the United States and his stay at Le Corbusier's atelier in 1952, along with other determining factors, such as Josef Albers's teaching residency at the Universidad Católica de Chile in 1953, (5) offered this group of architects formal references, and the ability to gauge the contribution of their work to the architectural culture.

Duhart's work experience in education and his knowledge of Richard Neutra's schools in California, appear to have been decisive factors in the prevailing criteria for the new Verbo Divino School. These North American schools share with Verbo Divino School and with all the educational buildings that these architects have carried out, similar considerations of 
Pareciera que la experiencia laboral de Duhart en materia educacional y su conocimiento de las escuelas californianas de Richard Neutra, fueron factores decisivos en los criterios del concurso para el nuevo Colegio del Verbo Divino. Esas escuelas norteamericanas compartirán con el colegio y con todos aquellos edificios educacionales que realizarán esos arquitectos, consideraciones similares de implantación en el solar y de la expresión abstracta de su arquitectura, que se hace visible en aspectos como la organización del partido general, la escala de los edificios y la preocupación por los elementos de control medioambiental, en el clima y geografía similares que comparten el estado de California y la zona central de Chile.

Algunas obras de esa tradición. El Colegio del Verbo Divino (Figs. 5 y 6) representa el inicio de esa nueva tradición educacional y una ruptura con los cánones anteriores de este tipo de edificaciones en Chile. El proyecto buscaba instaurar un modelo de enseñanza centrado en el ciclo de vida del estudiante y en estrecha relación de los recintos con los espacios exteriores, la naturaleza y las vistas al paisaje de la cordillera de los Andes. Las circulaciones fueron entendidas como espacios intermedios y los edificios potencian el contacto con el exterior, a través de su relación con patios, jardines y zonas deportivas. Para

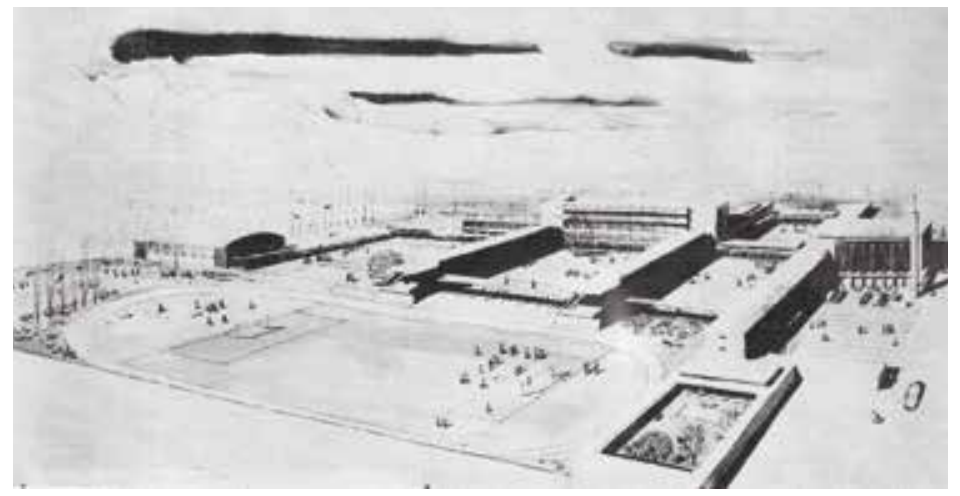

Fig. 5. Perspectiva Colegio del Verbo Divino hacia 1950. Anuario Colegio del Verbo Divino, año 1975

Fig. 6. Kindergarten del Colegio del Verbo Divino hacia 1962. Fotografía de Luis Ladrón de Guevara. Colección Museo Histórico Nacional de Chile.

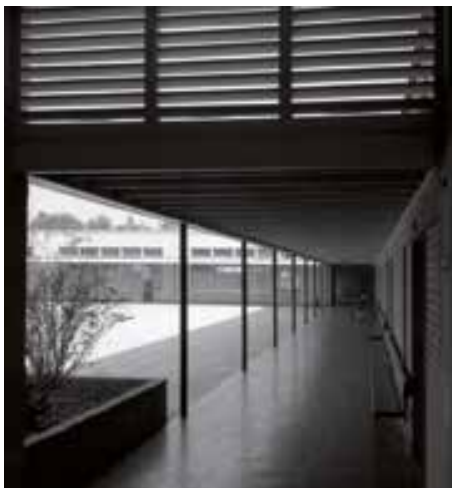

on-site building placement and the abstract expression of its architecture that can be seen in aspects like the organization of their overall disposition of the pavilions, the scale of the buildings and the concern for environmental control components for the similar climate and geography shared by the state of California and central Chile.

Some Works from that Tradition. Verbo Divino School (Figs. 5 \& 6) represents the beginning of this new educational tradition and a break from the previous canons of this type of building in Chile. The project sought to establish a teaching model centered on the student's life cycle, and on the close relationship of the premises with the outdoor areas, nature and the views of the Andes mountain range. Areas for circulation were understood as intermediate spaces and that buildings enhance our contact with the exterior through their relationship with patios, gardens and sports grounds. For this, the campus had different areas for each educational level, with a structure that is shaped by the layout of classrooms, and articulated by an orthogonal network of covered corridors. The model presents an ongoing concern for environmental control, understood as an essential component for architecture to contribute in bettering the pedagogical aspects of teaching. (Figs. $7 \& 8$ )

The early work on Verbo Divino School made its authors experts and precursors of a new model of educational architecture that was soon installed in the country, and undoubtedly contributed to this group of architects to be presented with other educational assignments, this being one of the main axes of their respective careers. 

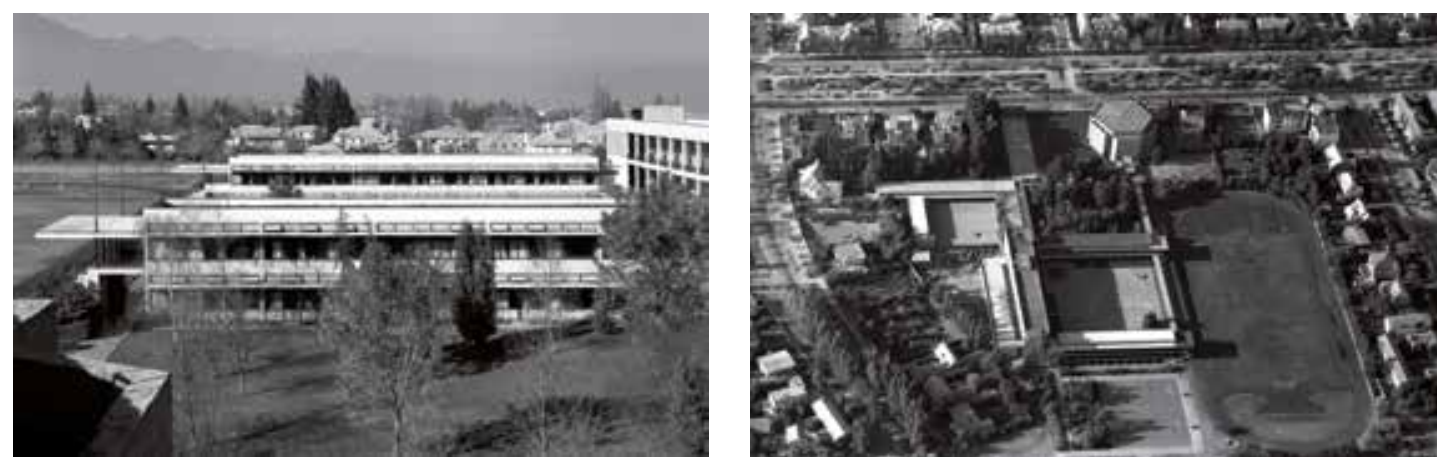

ello, el conjunto disponía áreas diferenciadas para cada uno de los niveles educativos, en una organización que se configura por la disposición de pabellones de aulas, articulados por una red ortogonal de corredores cubiertos. El conjunto presenta una constante preocupación por el control ambiental, entendido como un componente absolutamente necesario para contribuir desde la arquitectura a incrementar los aspectos pedagógicos de la enseñanza. (Figs. 7 y 8 )

La obra temprana del Colegio del Verbo Divino había convertido a sus autores en expertos y precursores de un nuevo modelo de arquitectura para la enseñanza que se instalaba en el país, e indudablemente contribuyó a que a este grupo de arquitectos se le presentaran otros encargos educacionales en años posteriores, siendo éste uno de los ejes principales de sus respectivas carreras.

Fig. 7. Colegio del Verbo Divino hacia 1962. Fotografía de Luis Ladrón de Guevara. Colección Museo Histórico Nacional de Chile Fig. 8. Fotografía aérea del Colegio del Verbo Divino hacia 1965. Archivo Central Andrés Bello

$\mathrm{Al}$ año siguiente de haber ganado ese concurso, la oficina de Larrain y Duhart, asociados con Exequiel Fontecilla y Hernán Mönckeberg, realizarán el proyecto del Seminario Pontificio Mayor de Santiago, (Fig. 9) un internado para la formación eclesiástica que se situaba en la comuna de Las Condes, por esos años un sector rural cercano a la pre-cordillera de los Andes. El conjunto educacional fue planteado también en un esquema de pabellones de diferentes tamaños y patios, articulados por corredores cubiertos y abo-

The year after winning the competition, Larrain \& Duhart Office, associated with Exequiel Fontecilla and Hernán Mönckeberg, carried out the project for the Seminario Pontificio Mayor in Santiago, (Fig. 9) a boarding school for ecclesiastical formation located in the district of Las Condes, in those years a rural sector near the lower ranges of the Andes. The educational complex was also projected in a scheme of different sized pavilions and courtyards, articulated by covered corridors with vaulted ceilings. The main body -an extensive building set in a manner of an elongated structure and a monolithic appearance- presented its façade with the expression of its program, its structure, its finishes and details. Unlike the school of the German religious body, the form of the Seminario Pontificio Mayor presented a sum of elements and lacked the solar control devices on the fronts, concentrating their architectural program in lesser volumes.

Just as in the Verbo Divino School, one of the most discussed aspects during the project was the definition of the form of the church, although in the case of the Seminario Pontificio Mayor the proposal was not materialized according to the ideas of the authors.

Larrain and Duhart were also responsible for the project of the Alianza Francesa School, (Fig. 10) inaugurated in 1959. The outline presents a careful layout of the volumes on the lot, freeing areas destined to playgrounds and gardens, presented in a pattern of covered corridors and courtyards, which enhance the visual relationship with the immediate outdoor areas and the views of the eastern parts of the city. This school also presents some inno- 

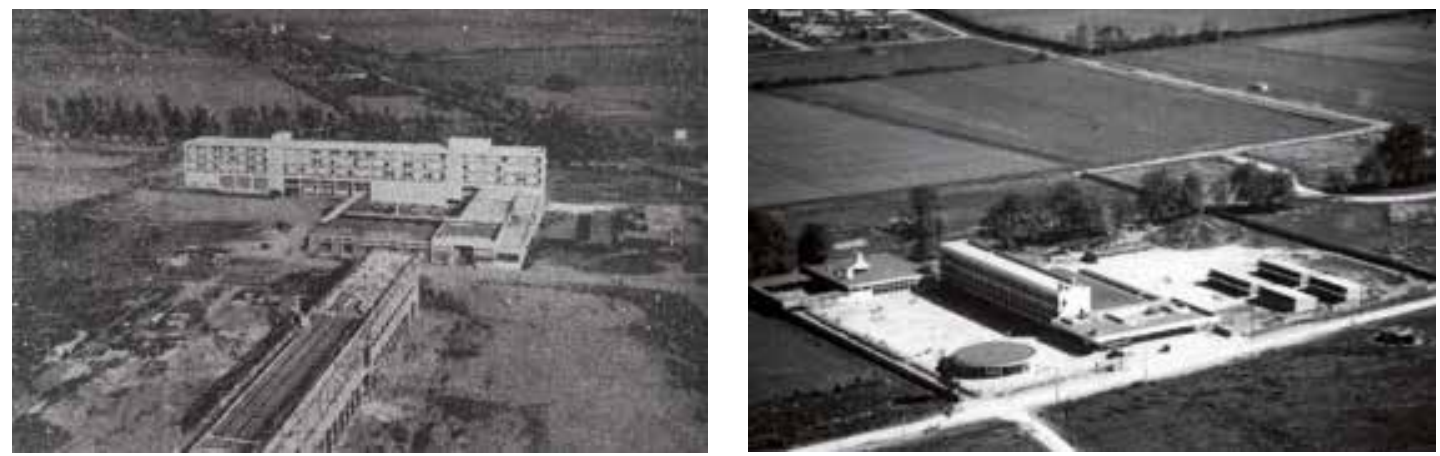

vedados. El cuerpo principal -un edificio de gran envergadura resuelto a la manera de una pastilla alargada y con apariencia monolítica- presentaba en su fachada la expresión de su programa de recintos, su estructura, los acabados y terminaciones. A diferencia del colegio de los religiosos alemanes, los cuerpos del Seminario Pontificio presentaban un sumatorio de elementos y carecían de dispositivos de control solar en las fachadas, concentrando en menos volúmenes el programa arquitectónico.

Tal y como había sucedido en el Colegio del Verbo Divino, la definición de la forma de la iglesia será uno de los aspectos más discutidos del proyecto, a pesar de que en el caso del Seminario Pontificio Mayor, la propuesta no será materializada según las ideas de sus autores.

Larrain y Duhart serán responsables además, del proyecto del Liceo de la Alianza Francesa, (Fig. 10) inaugurado en 1959. El esquema presenta una cuidada disposición de los volúmenes en el solar, liberando las áreas destinadas a patios de juego y jardines, inscritos en una trama de corredores y patios cubiertos que potencia la relación visual con los espacios exteriores inmediatos y las vistas al paisaje del sector oeste de la ciudad. Este liceo presenta además algunas innovaciones a nivel local respecto a los aspectos

Fig. 9. Vista aérea del Seminario Pontificio de Santiago hacia 1954. Archivo Seminario Pontificio de Santiago.

Fig. 10. Vista aérea del Liceo de la Alianza

Francesa hacia 1960. Corporación Educacional Alianza Francesa de Santiago.

vations on a local level regarding the pedagogical aspects of educational buildings: a circular kindergarten with hexagonal classrooms organized in the manner of a 'honeycomb', presented as a low and isolated volume, located near the main entrance of the establishment and classrooms on a single level, that leave independent areas for teaching outdoors.

The educational complex is articulated with a main body of four levels, built in reinforced concrete painted on white, characteristic that governs the whole construction. (Fig. 11) In its appearance, the relief and textures from the poured concrete and the masonry fillings of un-plastered pressed brick were left, as well as the metallic trellises that protect the classrooms from the sun. Over that pavilion a deck was built for activities like playing or as a place for music classes and choir.

The same company, along with Ignacio Covarrubias, was responsible for the planning of Compañía de María School, (Fig. 12) which was also emplaced in the eastern district of Santiago. The building for this women's religious congregation included a system of classrooms, quarters for nuns and novices and a church. The building presented some variables to this new educational tradition. For example, the whole structure was raised on two levels within a rectangular scheme, which inside freed a succession of interconnected courtyards. This area is partially elevated by a structure of rigid reinforced concrete frames that connects the common areas, freeing areas under the classroom pavilion, offering shaded areas and serving as a covered yard on rainy days. Over it, the structure features rein- 
pedagógicos de los edificios educacionales: un jardín infantil circular, con aulas hexagonales organizadas a la manera de un 'panal de abejas', se presenta como un volumen bajo y aislado situado cerca del acceso principal del establecimiento y aulas en un solo nivel dejan espacios independientes para impartir la docencia al aire libre.

El establecimiento educacional se articula con un cuerpo principal de cuatro niveles construido en hormigón armado y pintado de blanco, que domina el conjunto. (Fig. 11) En su expresión se dejó el relieve y las texturas que habían quedado marcados por el vaciado del hormigón y los rellenos de albañilería de ladrillo prensada sin estucar, celosías de estructura metálica para proteger del asolamiento a las aulas. Sobre ese pabellón se dejó una cubierta habitable, que fue pensada como patio de juegos y lugar para las clases de canto y música.

La misma sociedad, junto con Ignacio Covarrubias será responsable del Colegio Compañía de María, (Fig. 12) que se instaló también en el sector oeste de Santiago. El edificio de esta congregación religiosa de mujeres incluía un programa de aulas, habitaciones para monjas y novicias y una iglesia. El edificio presentaba algunas variables a esa nueva tradición educacional. Por ejemplo, el conjunto fue planteado en dos niveles inscritos
Fig. 11. Liceo de la Alianza Francesa hacia 1960. Archivo de Originales FADEU-PUC.

Fig. 12. Colegio Compañía de María hacia 1960. Fotografía de Luis Ladrón de Guevara. Colección Museo Histórico Nacional de Chile
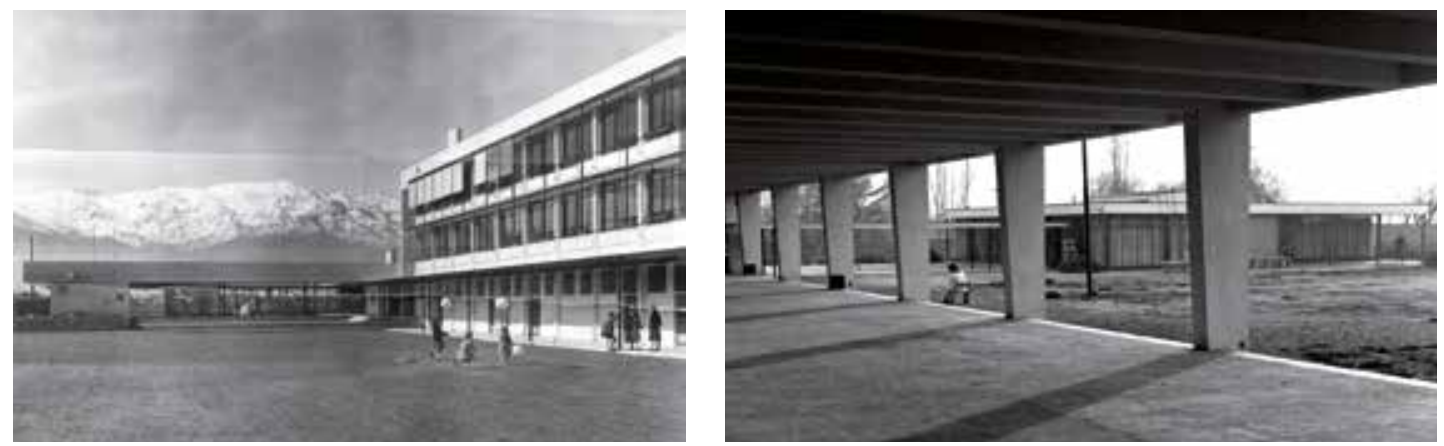

forced concrete sunshades, metallic carpentry work and glass surfaces, protecting the classrooms from excessive sunlight. At the center of the complex, a church was projected, which represented the highest level of hierarchy and acted as an articulator of the entire site, but it was never built, like the rest of the perimeter of the original plan. A detached, single-level and more transparent structure was proposed for the kindergarten, connected to the rest of the building by a covered passageway.

Also, during those years, the competition for the new Valparaiso Naval School (Fig. 13) was held. The winning proposal, led by Pérez de Arce, included several members of other teams that had been eliminated in the initial stage of that competition. (6) Although the program for the Naval School presented different characteristics than the rest of the cases under review, this colossal work would carry out several of the aforementioned principles to much greater extremes, such as the organization of the whole structure through the articulation of linear pavilions and covered corridors, and its visual relationship with the bay of Valparaiso. Possibly the most striking aspect of this proposal was precisely the monumentality, unconventionality, and formal expression of its volumes, their vertical circulations, courtyards and platforms, and their abstract correlation with the geography surrounding it.

In those years another notable building was erected in Chile, which enriched the body of this educational tradition: the Universidad Técnica del Estado, (Fig. 14) a project led by the Bresciani, Valdés, Castillo \& Huidobro Office. In the same manner as a campus, the complex is configured through the careful layout of the buildings on a lot, with pavilions of diffe- 


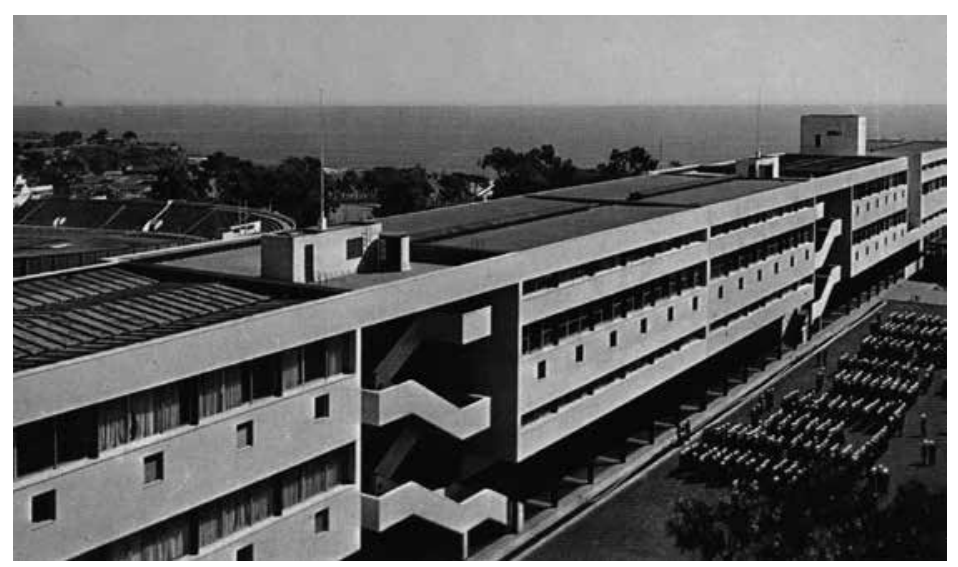

en un esquema rectangular, que liberaba en su interior una sucesión de patios interconectados. Ese cuerpo aparece parcialmente levantado gracias a una estructura de marcos rígidos de hormigón armado que conecta los espacios comunes, liberando superficies bajo el pabellón de aulas, que entregaban espacios de sombra y que sirve como patio cubierto en los días de lluvia. Sobre él, la estructura presenta parasoles de hormigón armado, carpinterías metálicas y superficies acristaladas, cuidando el asoleamiento en el interior de las aulas. Al centro del conjunto se planteó una iglesia, que era el volumen de mayor jerarquía y articulador del conjunto, la cual no fue construida, al igual que el resto del perímetro del partido general original. Un cuerpo aislado, de un solo nivel y más transparente, estaba destinando al jardín infantil y se conectaba al resto del conjunto por una circulación cubierta.

En esos años además, se realizó el concurso para la nueva Escuela Naval de Valparaíso (Fig. 13) cuya propuesta ganadora fue liderada por Pérez de Arce e incluyó a varios de los integrantes de equipos que habían quedado descartados en el primer grado de esa competición. (6) Si bien el
Fig. 13. Escuela Naval de Valparaíso. Fotografía de Ismael Espinosa. Colección Postales Inventadas.

rent sizes for classrooms, laboratories and workshops, all articulated through courtyards and covered corridors. Possibly due to the technological and scientific nature of its teachings, this educational complex was erected with a mixed structural system, where metal structures fortified with reinforced concrete give the façade an abstract expression, through the composition of thresholds, lattice work, steelwork and glass surfaces. This approach must be understood as a constructive innovation in Chile in those years, which used environmental control as a criterion for defining the architectural form, and in the plastic and spatial quality presented by constructive solutions, all within the technological spirit of the institution.

A result of this tradition, and possibly one of the most prominent cases, is San Ignacio El Bosque School, (Fig. 15) built in Santiago during the late fifties, which is the work of Piwonka, who associated in its initial stage with Schmidt. The project presents a radical approach to pedagogical space, deepening the ideas that Piwonka had materialized with a team in Verbo Divino School, but giving the work an exceptional modern lift. The complex, which carefully arranges the volumes on the site, poses with greater force than in the previous cases its monumentality and abstraction, through the articulation of linear, cohesive and compact volumes, its great elegance and plastic expression -resulting from constructive and material considerations- and the presence of structural elements, coatings, finishes and color use, as well as the integration of abstract art to its architecture. (Figs. $16 \& 17$ )

Altogether, the volumes are clearly organized under the usual scheme of linear pavilions articulated by patios and gardens, and connected by an expressive network of corridors and covered courtyards. In this work, the environmental control necessary for the educational activity persists as a central consideration, incorporating in each building environmental 
programa de la academia naval presentaba particularidades distintas del resto de los casos revisados, esta colosal obra llevará al extremo varios de los principios antes expuestos, como la organización del conjunto a través de la articulación de pabellones lineales y pasos cubiertos, y la relación visual con la bahía de Valparaíso. Posiblemente, lo más llamativo de esta propuesta sea precisamente la monumentalidad, radicalidad y expresión formal de los volúmenes, sus circulaciones verticales, patios y plataformas y su relación abstracta con la geografía que la rodea.

En esos años se levantó en Chile además otra edificación notable que enriqueció el cuerpo de esa tradición educacional: la Universidad Técnica del Estado, (Fig. 14) proyecto liderado por la oficina Bresciani, Valdés, Castillo y Huidobro. A la manera de un campus, el conjunto se configura a través de la cuidada disposición de los edificios en el solar, con pabellones de distintos tamaños para aulas, laboratorios y talleres, que se articulan entre ellos a través de patios y corredores cubiertos. Posiblemente, por el carácter tecnológico y científico de su enseñanza, este conjunto educacional fue levantado con un sistema estructural mixto, donde predominan las estructuras metálicas reforzadas con elementos de hormigón armado,

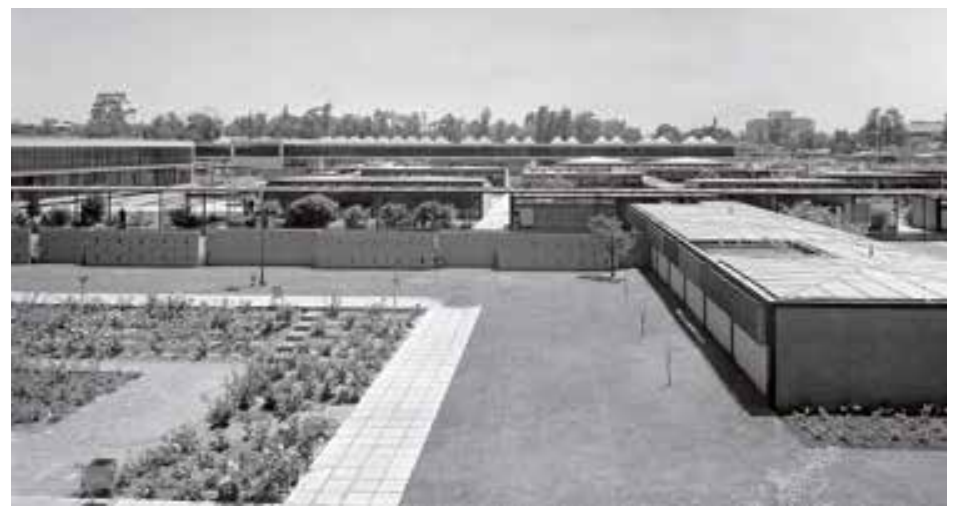

Fig. 14. Universidad Técnica del Estado hacia 1964. Fotografía de René Combeau. Archivo de Originales FADEU-PUC.

control devices, such as sunshades and trellises. The differentiation of the stages of the educational cycle -incorporating areas of independent halls and courtyards in the complex- presents solutions that enrich this architectural creation. In particular, the different ways of handling circulations, stairwells, corridors and covered courtyards provides attractive areas of light and shade, allowing to teach outside of the classroom, especially in the section for younger children. (7) The intermediate areas, the treatment of courtyards and gardens, the landscaping and the relationship of architecture with the landscape of the Andes Mountains also foster pedagogical aspects. (Figs. 18 \& 19)

In perspective. This series of works evidences an extraordinary moment in Chilean architectural culture, in an age in which the idea was to promote a collective project, that spanned from the field of teaching to the professional practice of architecture. The whole of this architectural production also reveals the travels, reception and development in Chile of ideas, regarding modernity in a limited artistic-cultural environment and the materialization of these ideas in a remarkable group of works and projects.

In them, it is possible to find constants, pertinences and evident feedback, sharing similar approaches, such as the careful positioning of the buildings within the lots, its relationship with the landscape and the environment, the environmental considerations or the understanding of the technicalities needed for educational space. It is also possible to establish impressions on more general topics, such as the construction technique in a seismic country and its plastic expression and in some cases, on the incorporation of the arts or landscaping into the architectural project, in order to respond, from the field of architecture, to the teaching needs of schooling. (8) 


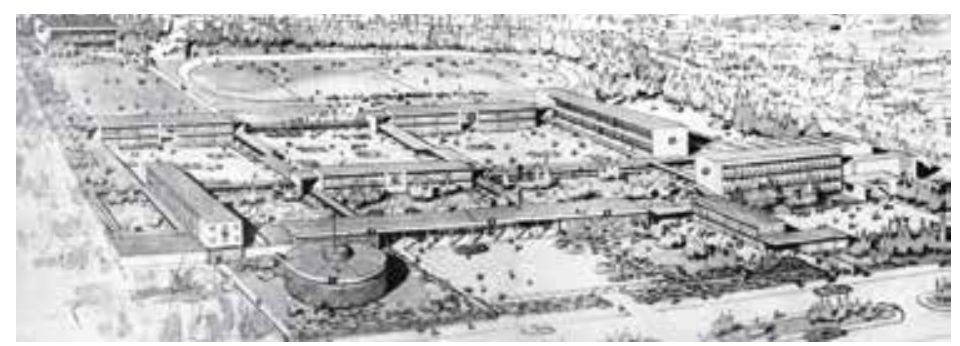

que entregan una expresión abstracta a sus fachadas, a través de la composición de vanos, celosías, carpinterías de acero y superficies acristaladas. Esta aproximación debe ser entendida como una innovación constructiva en Chile, que mantenía el control medioambiental en los criterios de definición de la forma arquitectónica y en la calidad plástica y espacial que presentan las soluciones constructivas, en coherencia con el espíritu tecnológico de la institución.

Como un corolario de esa tradición y posiblemente como uno de los casos más destacados, se encuentra el Colegio San Ignacio El Bosque, (Fig. 15) levantado en Santiago a finales de la década de los cincuenta, que es obra de Piwonka asociado en una primera etapa con Schmidt. El proyecto presenta una radicalidad en sus planteamientos en torno al espacio pedagógico, profundizando las ideas que había materializado el propio Piwonka en el Colegio del Verbo Divino, pero dando a la obra un vuelo moderno excepcional. El conjunto, que disponía cuidadosamente los volúmenes en el solar, planteaba con mayor fuerza que en los casos anteriores una monumentalidad y abstracción, a través de la articulación de volúmenes lineales cohesionados y compactos de gran prestancia y expresión plástica, que resulta de las consideraciones constructivas y materiales, la presencia de los elementos estructurales, revestimientos, acabados, el uso color y la integración del arte abstracto a su arquitectura. (Figs. 16 y 17)

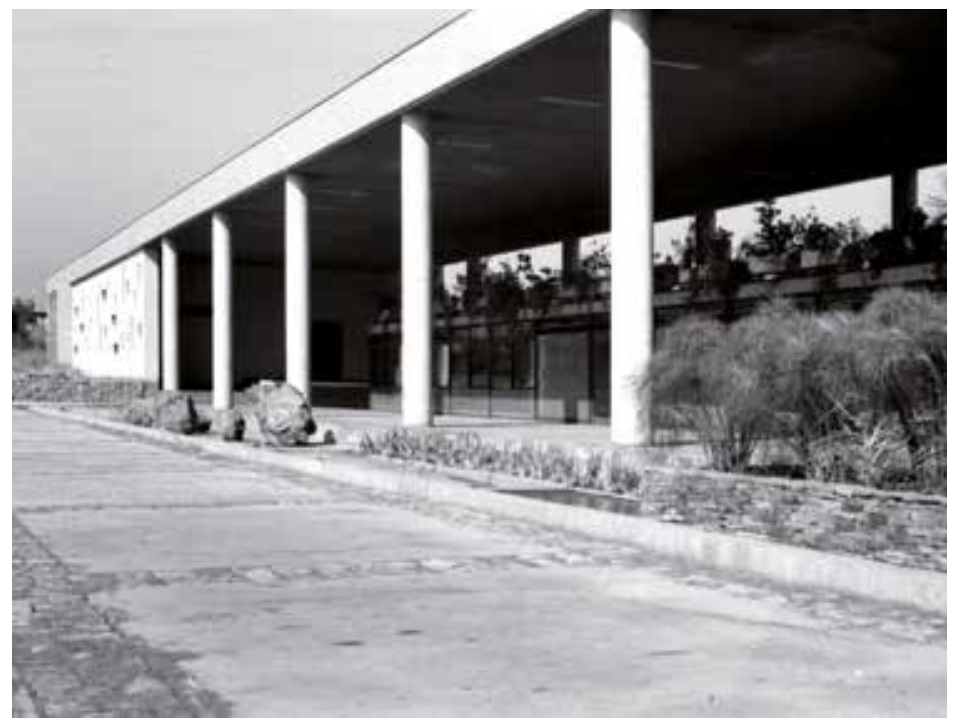

Fig. 15. Perspectiva aéreadel anteproyecto del Colegio San Ignacio El Bosque. Anuario Colegio San Ignacio 1959

Fig. 16. Pabellón de acceso del Colegio San Ignacio El Bosque hacia 1962. Fotografía de Alberto Piwonka. Archivo familia Alberto Piwonka Fig. 17. Pabellón de acceso Colegio del San Ignacio El Bosque hacia 1962. Fotografía de Alberto Piwonka. Archivo familia Alberto Piwonka.

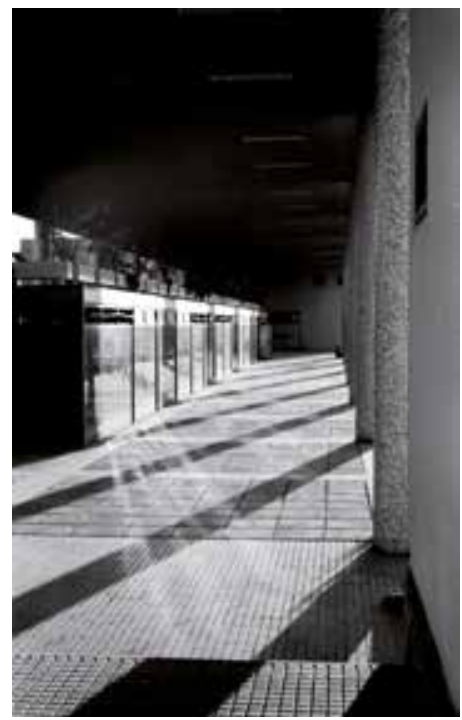


En el conjunto, los volúmenes se organizan con claridad, bajo el usual esquema de pabellones lineales articulados por patios y jardines y conectados por una expresiva red de corredores y patios cubiertos. En esta obra persiste como una consideración central, el control medioambiental necesario para el proceso educativo, que incorpora en cada edificio dispositivos de control ambiental como parasoles y celosías. La diferenciación de las etapas del ciclo educativo -incorporando sectores de salas y patios independientes en el conjunto- presenta soluciones que enriquecen esa producción arquitectónica. En especial, destacan las diferentes maneras de tratar las circulaciones, cajas de escaleras, corredores y patios cubiertos, que creaban atractivos espacios de luz y de sombra que posibilitaban la docencia al exterior de las aulas, en especial en el área para los niños más pequeños. (7) Los espacios intermedios, el tratamiento de patios y jardines, el paisajismo y la relación de la arquitectura con el paisaje y la cordillera de los Andes fomentan, además, los aspectos pedagógicos. (Figs. 18 y 19)

En perspectiva. Esta serie de obras evidencia un momento extraordinario de la cultura arquitectónica chilena, en un período en que se buscaba impulsar un proyecto colectivo que traspasaba desde la docencia a la práctica profesional de la arquitectura. El conjunto de esta producción arquitectónica da cuenta además del viaje, recepción y desarrollo en Chile de las ideas de modernidad en un reducido ambiente artístico-cultural y la materialización de esas ideas en un conjunto notable de obras y proyectos.

En ellas es posible encontrar constantes y pertinencias y una evidente retroalimentación, compartiendo aproximaciones similares, como la cuidada situación de los edificios en el lugar, la relación con el paisaje y el entorno, las consideraciones medioambientes o el entendimiento del tecnicismo necesario para el espacio educativo. En ellas es posible establecer además, lecturas en torno a temáticas más generales, como la técnica constructiva en un país sísmico y su expresión plástica y en algunos casos, en la integración de las artes o el paisajismo al proyecto arquitectónico para dar respuesta desde la arquitectura a las necesidades pedagógicas de la enseñanza. (8)
Fig. 18. Jardín central, pabellón de humanidades y corredores cubiertos del Colegio San Ignacio E Bosque hacia 1962. Archivo Compañía de Jesús. Fig. 19. Corredores cubiertos, prefectura y pabellón de humanidades del Colegio San Ignacio El Bosque hacia 1964. Archivo familia Alberto Piwonka.
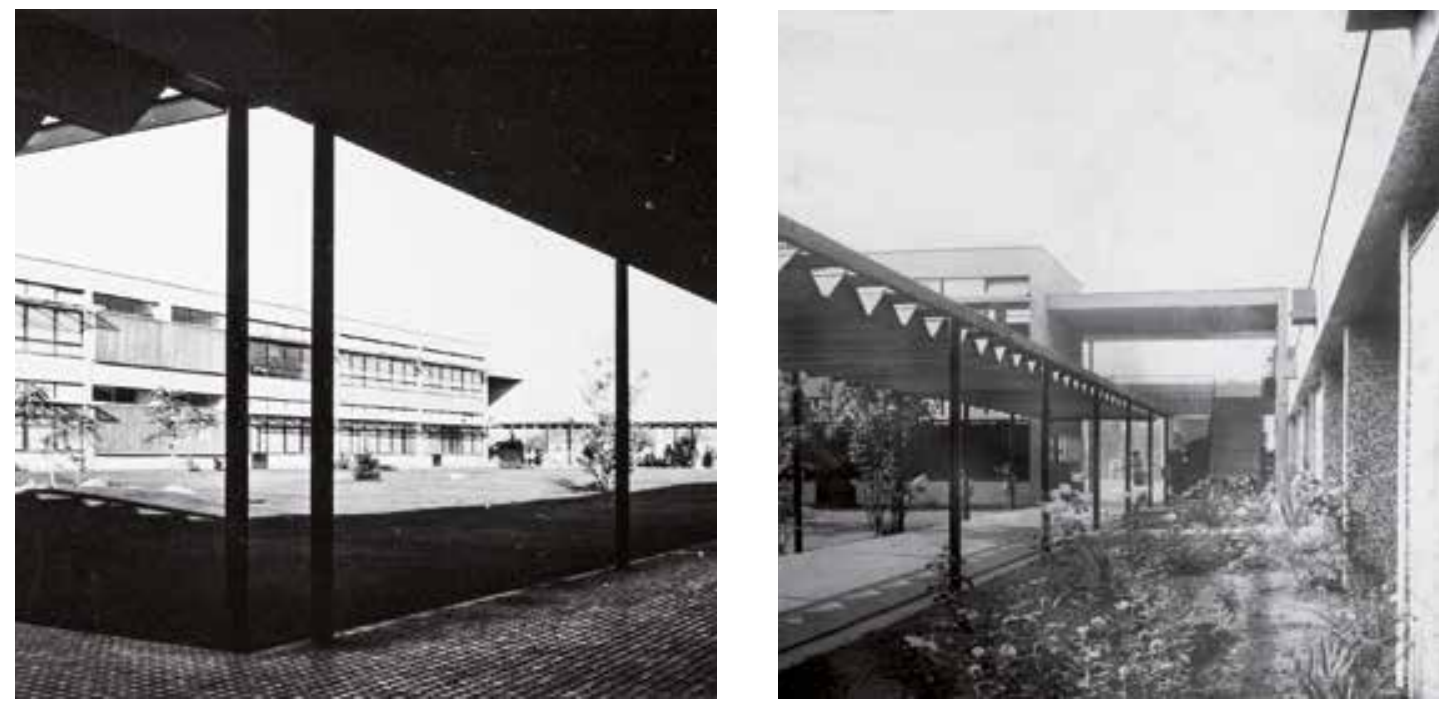


\section{NOTAS}

1. La reforma de la Escuela de Arquitectura de la Universidad Católica de Chile en 1949 debe ser entendida como un largo y engorroso proceso interno que se inicia en 1944, pero que concluye con todos sus alcances cuando Sergio Larrain se convierte en Decano, en 1953. En la Universidad de Chile sucedió un proceso similar, concretado con anterioridad en 1945. Ver MOLINA, Cristóbal. Alberto Piwonka: en el cruce de las ideas de la modernidad en Chile. Tesis doctoral inédita, ETSAB-UPC, 2016.

2. En paralelo además, se realizaron importantes obras privadas con principios similares pero con variantes, ya sea en su sistema de organización como en su expresión formal. El Santiago College (1932) -institución ligada a los misioneros metodistas americanos- o el edificio educacional de la Fundación Federico Santa María (1926) dedicada a las artes y oficios, ambos de la firma Smith Solar \& Smith Miller, así como el Colegio Universitario Inglés (1937), del mismo Mönckeberg, fueron obras importantes de esos años.

3. Este concurso se falló prácticamente en paralelo al concurso que ganan Larrain, Duhart, Pérez y Piwonka para el Colegio del Verbo Divino. Es más, los resultados de ambos concursos fueron publicados en Chile en el mismo número de la revista Arquitectura y Construcción, como ejemplos destacados de la nueva arquitectura educacional. Ver DESCONOCIDO. 'El nuevo liceo alemán'. Arquitectura y Construcción n. 14 de 1948. p. 16.

4. Entre 1942 y 1943 Duhart realizó un Máster en Arquitectura en la Graduate School of Design (GSD) de la Universidad de Harvard, donde fue alumno de Walter Gropius y Marcel Breuer y asistió a conferencias de László MoholyNagy, György Kepes y Sigfried Giedion, entre otros.

5. La estadía de Josef Albers en la Escuela de Arquitectura de la Universidad Católica se produce en 1953, por gestiones realizadas por Duhart a petición del entonces Decano, Larrain. En Chile, el alemán dictó el taller de Composición Pura, de orientación abstracta, junto a Piwonka en los dos primeros años de la enseñanza de la arquitectura. Ver MOLINA, Cristóbal. Alberto Piwonka: en el cruce de las ideas de la modernidad en Chile. Tesis doctoral inédita, ETSAB-UPC, 2016.

6. Pérez de Arce se presentará a la instancia definitiva con un extenso equipo formado además por Jaime Besa, Germán Brandes, Fernando Castillo, Ismael Echeverría, Hugo Gaggero, Hernán Labarca, Sergio Larrain y Arturo Urzúa. 7. La solución de las preparatorias del Colegio San Ignacio El Bosque mantiene una cercanía con las ideas planteadas en las aulas de Richard Neutra en la década de los años treinta, las de Josep Lluis Sert y Paul Lester Weiner para las escuelas primarias en el proyecto no construido de la Cidade dos Motores en 1946, o en la escuela de Munckegaard de Jacobsen, realizada en Dinamarca entre 1951 y 1958. 8. Este texto es una adaptación parcial de algunos de los contenidos de la tesis doctoral del autor, que fue leída en la Escuela Técnica Superior de Arquitectura de Barcelona de la Universidad Politécnica de Cataluña (ETSAB, UPC). en septiembre del 2016.

\section{REFERENCIAS}

BOZA, Cristián. Sergio Larrain G-M: La Vanguardia como propósito. Bogotá: Escala Colección SomoSur, 1990.

ELIASH, Humberto. Fernando Castillo: de lo moderno a lo real. Bogotá: Escala Colección SomoSur, 1990.

MOLINA, Cristóbal. Alberto Piwonka: en el cruce de las ideas de la modernidad en Chile. Tesis doctoral inédita, ETSAB-UPC, 2016.

MOLINA, Cristóbal. 'Modernidad y edificación escolar en Chile'. En AAVV. Documentos de Arquitectura Moderna en América Latina 1945 - 1965.

Ediciones UPC-Institut Català de Cooperació Iberoamericana, Barcelona, España 2014. pp 220-223.

MOLINA, Cristóbal. Concursos de arquitectura en Chile: su aporte al desarrollo cultural y a la calidad de vida. Santiago: Publicaciones Cultura, 2014. MONTEALEGRE, Alberto. Emilio Duhart Arquitecto. Santiago: Ediciones ARQ, 1994.

PÉREZ OYARZUN, Fernando. Bresciani Valdés Castillo Huidobro. Santiago: Ediciones ARQ, 2006.

PÉREZ OYARZUN, Fernando; BANNEN L., Pedro; RIESCO G., Hernán; URREJOLA D., Pilar. Iglesias de la modernidad en Chile: precedentes europeos y americanos. Santiago: Ediciones ARQ, 1997.

RODRÍGUEZ, León. Mario Pérez de Arce. La permanencia de la Arquitectura Moderna en Chile. Santiago: Ediciones ARQ, 1996.
NOTES

1. The reform at the School of Architecture of the Universidad Católica de Chile in 1949 should be understood as a long and cumbersome internal process that began in 1944 and ended, in all of its dimensions when Sergio Larrain assumed as Dean in 1953. The Universidad de Chile previously underwent a similar process, which was concluded in 1945. See MOLINA, Cristóbal. Alber to Piwonka: en el cruce de las ideas de la modernidad en Chile. Unpublished doctoral thesis, ETSAB-UPC, 2016.

2. Simultaneously, important private works were also carried out with similar principles but with variations, either in their organizational system or their formal expression. The Santiago College (1932) -institution associated to the American Methodist missionaries- or the educational building of the Fundación Federico Santa María (1926) dedicated to arts and crafts, both by the firm Smith Solar \& Smith Miller, or the Universitario Inglés (1937) by Mönckeberg, were important works during those years.

3. This contest was practically refereed in parallel with the contest won by Larrain, Duhart, Pérez and Piwonka for the Verbo Divino School. The results of both competitions were published in Chile in the same issue of the magazine Arquitectura y Construcción, as outstanding examples of the new educational architecture. See UNKNOWN. 'El Nuevo liceo alemán'. Arquitectura y Construcción, n. 14, 1948. p 16.

4. Between 1942 and 1943 Duhart completed a Master's Degree in Architecture at Harvard's Graduate School of Design (GSD), where he was a student of Walter Gropius and Marcel Breuer, and attended lectures by László Moholy-

Nagy, GyörgyKepes and Sigfried Giedion, among others.

5. The residency of Josef Albers at the School of Architecture of the Universidad Católica was thanks to Duhart's request to the then Dean Larrain, in 1953. In Chile, the German artist dictated the workshop of Pure Composition of abstract orientation, with Piwonka, offered for the initial two years of studies for the Degree in Architecture. See MOLINA, Cristóbal. Alberto Piwonka: en el cruce de las ideas de la modernidad en Chile. Unpublished doctoral thesis, ETSAB-UPC, 2016.

6. In the final stages of the competition, Pérez de Arce presented his extensive team formed by Jaime Besa, Germán Brandes, Fernando Castillo, Ismael Echeverría, Hugo Gaggero, Hernán Labarca, Sergio Larrain and Arturo Urzúa.

7. The solution for the San Ignacio El Bosque High-School shows a connection with the ideas put forward in the Neutra classrooms of the thirties, by Josep Lluis Sert and Paul Lester Weiner for primary schools in the never-built assignment of Cidade dos Motoresin, at 1946 or the Munckegaard School in Denmark, made by Jacobsen between 1951 and 1958.

8. This text is a partial adaptation of some of the author's doctoral thesis, which was read at the Universidad Politécnica de Cataluña (ETSAB, UPC). in September, 2016.

\section{REFERENCES}

BOZA, Cristián. Sergio Larrain G-M: La Vanguardia como propósito. Bogotá: Escala Colección SomoSur, 1990.

ELIASH, Humberto. Fernando Castillo: de lo moderno a lo real. Bogotá: Escala Colección SomoSur, 1990.

MOLINA, Cristóbal. Alberto Piwonka: en el cruce de las ideas de la modernidad en Chile. Tesis doctoral inédita, ETSAB-UPC, 2016.

MOLINA, Cristóbal. 'Modernidad y edificación escolar en Chile'. En AAVV., Documentos de Arquitectura Moderna en América Latina 1945 - 1965.

Ediciones UPC-Institut Català de Cooperació Iberoamericana, Barcelona, España 2014. pp 220-223.

MOLINA, Cristóbal. Concursos de arquitectura en Chile: su aporte al desarrollo cultural y a la calidad de vida. Santiago: Publicaciones Cultura, 2014. MONTEALEGRE, Alberto. Emilio Duhart Arquitecto. Santiago: Ediciones ARQ, 1994.

PÉREZ OYARZUN, Fernando. Bresciani Valdés Castillo Huidobro. Santiago: Ediciones ARQ, 2006.

PÉREZ OYARZUN, Fernando; BANNEN L., Pedro; RIESCO G., Hernán; URREJOLA D., Pilar. Iglesias de la modernidad en Chile: precedentes europeos y americanos. Santiago: Ediciones ARQ, 1997.

RODRÍGUEZ, León. Mario Pérez de Arce. La permanencia de la Arquitectura Moderna en Chile. Santiago: Ediciones ARQ, 1996. 